\title{
PENGARUH PENGUASAAN MAHASISWA PADA MATA KULIAH PRASYARAT TERHADAP MATA KULIAH PERSAMAAN DIFERENSIAL DIJURUSAN PENDIDIKAN MATEMATIKA TAHUN AKADEMIK 2013/2014
}

\author{
Oleh \\ Muhammad Amin Paris dan Hasby Assidiqi
}

\begin{abstract}
Abstrak
Persamaan Diferensial adalah mata kuliah yang tersaji pada semester genap, yaitu semester IV (empat). Mata kuliah ini dapat diprogramkan jika mata kuliah prasyarat seperti mata kuliah Kalkulus A, Kalkulus B dan Kalkulus Lanjutan sudah terselesaikan. Oleh karena itu penelitian ini bertujuan untuk mengetahui pengaruh penguasaan mahasiswa pada mata kuliah prasyarat terhadap mata kuliah persamaan diferensial di Jurusan PMTK Tahun Akademik 2013/2014. Berdasarkan hasil penelitian menunjukkan bahwa: Kalkulus A berpengaruh nyata terhadap kalkulus B, Kalkulus A berpengaruh nyata terhadap kalkulus Lanjutan dan persamaan diferensial, Kalkulus B berpengaruh nyata terhadap kalkulus Lanjutan dan persamaan diferensial, dan Kalkulus Lanjutan tidak berpengruh nyata terhadap persamaan diferensial.
\end{abstract}

\section{Kata Kunci: Mata Kuliah Prasyarat, Persamaan Diferensial}

\section{A. Pendahuluan}

1. Latar Belakang Masalah

Persamaan Diferensial adalah mata kuliah yang tersaji pada semester genap, yaitu semester IV (empat). Mata kuliah ini dapat diprogramkan jika prasyarat-prasyarat mata kuliah seperti Kalkulus A, Kalkulus B dan Kalkulus Lanjutan sudah terselesaikan. Selain itu mata kuliah ini juga merupakan prasyarat bagi mata kuliah lainnya seperti Masalah Nilai Awal dan Batas 
(MNAB), Metode numerik serta Analisis Real. Terkait dengan materi mata kuliah ini, konsep dan pemecahan masalah pada persamaan diferensial lebih banyak melibatkan konsep dasar pada mata kuliah prasyarat. Sebagai ilustrasi perhatikan persamaan diferensial berikut:

$$
\left(x^{2}-y\right) d x-x d y=0 \text { atau } \frac{d y}{d x}=\frac{\left(x^{2}-y\right)}{x}
$$

Untuk menentukan solusi dari persamaan diferensial tersebut di atas, maka langkah-langkah pengerjaannya banyak melibatkan konsep turunan dan integral yang pernah dipelajari di mata kuliah prsayarat. Oleh karenanya penguasaan terhadap mata kuliah prasyarat sangat membantu dalam mengikuti perkuliahan pada mata kuliah persamaan diferensial.

Realita di lapangan, berdasarkan pengalaman penulis yang setiap semester genap selalu memegang mata kuliah ini melihat bahwa kemampuan mahasiswa didik masih belum memuaskan. Hal ini dapat dilihat dari rata-rata hasil prestasi akademik mahasiswa dari tahun 2008-2012 pada Tabel 1 berikut:

\begin{tabular}{|c|c|c|c|c|c|c|}
\hline \multirow{2}{*}{ Tahun } & \multirow{2}{*}{ Kelas } & \multirow{2}{*}{ Rata-Rata } & \multicolumn{4}{|c|}{ Jumlah Peserta didik } \\
\cline { 4 - 7 } & & & \multicolumn{2}{|c|}{ Tuntas } & \multicolumn{2}{|c|}{ Tidak Tuntas } \\
\cline { 4 - 7 } & & Jumlah & $(\%)$ & Jumlah & $(\%)$ \\
\hline \multirow{2}{*}{2009} & A & 64,88 & 29 & 0,71 & 12 & 0,29 \\
\cline { 4 - 7 } & B & 64,81 & 18 & 0,64 & 10 & 0,36 \\
\hline \multirow{2}{*}{2010} & A & 61,49 & 12 & 0,50 & 12 & 0,50 \\
\cline { 2 - 7 } & B & 60,04 & 15 & 0,63 & 9 & 0,37 \\
\hline \multirow{2}{*}{2011} & A & 64,99 & 15 & 0,71 & 6 & 0,29 \\
\cline { 2 - 7 } & B & 60,92 & 13 & 0,52 & 12 & 0,48 \\
\hline \multirow{2}{*}{2012} & A & 65,72 & 28 & 0,67 & 14 & 0,23 \\
\cline { 2 - 7 } & B & 64,25 & 36 & 0,84 & 17 & 0,16 \\
\hline
\end{tabular}

(Sumber: Dosen pengampu mata kuliah Persamaan Diferensial Fakultas Tarbiyah Jurusan PMTK)

Pada Tabel 1 di atas, memperlihatkan bahwa rata-rata kumulatif mahasiswa dari tahun 2008 - 2012 sebesar 63,78. Hal ini menunjukkan bahwa secara keseluruhan mahasiswa yang mengikuti perkuliahan dalam kategori cukup baik. Selain itu jika dilihat dari ketuntasan maupun yang ketidaktuntasan, rata-rata mahasiswa yang tidak tuntas dan tuntas sebanyak 12 dan 21 orang. 
Ketidaktuntasan mahasiswa terhadap mata kuliah persamaan diferensial diakibatkan tidak mampunya mahasiswa mengerjakan soal-soal persamaan diferensial yang melibatkan konsep turunan dan integral. Berbagai upayapun juga telah dilakukan penulis agar kemampuan mahasiswa pada mata kuliah meningkat. Salah satunya adalah melakukan pembelajaran inovatif dengan melakukan penerapan pembelajaran Problem Solving pada Persamaan Diferensial. Namun hasil penelitian tersebut menunjukkan bahwa prestasi mahaswa yang diajar dengan pembelajaran problem solving tidak berpengaruh secara signifikan. Oleh karena itu, permasalahan tersebut sangatlah perlu diteliti, hal ini agar dapat mengoptimalkan hasil belajar mahasiswa pada mata kuliah Persamaan Diferensial.

Berdasarkan uraian di atas, kiranya menarik dilakukan penelitian dengan judul” Pengaruh Penguasaan Mahasiswa Pada Mata Kuliah Prasyarat Terhadap Mata Kuliah Persamaan Diferensial Di Jurusan Pendidikan Matematika (PMTK) Tahun Akademik 2013/2014"

\section{Rumusan Masalah}

Berdasarkan masalah di atas, maka penelitian ini dapat dirumuskan sebagai berikut: Apakah penguasaan mata kuliah prasyarat berpengaruh secara signifikan terhadap mata kuliah persamaan diferensial di Jurusan PMTK Tahun Akademik 2013/2014.

\section{Tujuan Penelitian}

Penelitian ini bertujuan untuk: mengetahui pengaruh penguasaan mahasiswa pada mata kuliah prasyarat terhadap mata kuliah persamaan diferensial di Jurusan PMTK Tahun Akademik 2013/2014.

\section{B. Metodologi Penelitian}

1. Jenis dan Pendekatan Penelitian

Penelitian ini dirancang sebagai penelitian eksplanasi untuk menjelaskan pengaruh penguasaan mahasiswa pada mata kuliah prasyarat terhadap mata kuliah persamaan diferensial di Jurusan Pendidikan Matematika IAIN Antasari Banjarmasin Tahun Akademik 2013/2014. Sedangkan pendekatan yang 
digunakan adalah pendekatan kuantitatif. Menurut (Saifuddin Azwar, 2005), “penelitian dengan pendekatan kuantitatif menekankan analisisnya pada datadata numerikal (angka) yang diolah dengan metode statistika”.

2. Populasi dan Sampel Penelitian

a. Populasi

Populasi adalah keseluruhan individu yang menjadi subjek penelitian (Suharsimi Arikunto, 2010). Dalam penelitian ini yang dijadikan populasi adalah semua mahasiswa yang telah mengikuti mata kuliah Kalkulus A, Kalkulus B dan Kalkulus Lanjutan serta Persamaan Diferensial untuk angkatan $2011 / 2012$.

b. Sampel

Sampel adalah sebagian atau wakil populasi yang diteliti. Terkait penelitian ini semua mahasiswa dalam anggota populasi dijadikan sampel sebanyak 65 orang.

\section{Sumber Data}

Pada penelitian ini, sumber data yang digunakan adalah data sekunder, yaitu data yang diperoleh melalui bagian akademik jurusan Pendidikan Matematika yang berupa nilai mata kuliah kalkulus A, Kalkulus B, Kalkulus Lanjut dan Persamaan Diferensial untuk mahasiswa angkatan 2011/2012.

4. Uji Asumsi Klasik

Sebelum dilakukan pengujian dengan analisis jalur, maka terlebih dahulu perlu dilakukan suatu pengujian untuk mengetahui ada tidaknya pelanggaran terhadap asumsi-asumsi klasik. Menurut (Ghozali, 2009) asumsi klasik meliputi uji normalitas, uji multikolinieritas, uji autokorelasi, uji heteroskedastisitas.

a. Uji Normalitas

Menurut (Jonathan Sarwono, 2010) uji normalitas adalah sebuah pengujian yang dilakukan untuk mengecek apakah data yang sedang diteliti berasal dari populasi yang mempunyai sebaran normal. Adapun bentuk hipotesis yang diajukan adalah sebagai berikut: 
$H_{0}$ : Data nilai mahasiswa pada mata kuliah kalkulus $\mathrm{A}$, kalkulus $\mathrm{B}$, kalkulus lanjut dan persamaan diferensial tidak berdistribusi normal.

$H_{1}$ : Data nilai mahasiswa pada mata kuliah kalkulus $\mathrm{A}$, kalkulus $\mathrm{B}$, kalkulus lanjut dan persamaan diferensial berdistribusi normal.

Uji yang digunakan adalah uji Kolmogorov-Smirnov dengan bantuan software SPSS $17 . \quad$ Uji ini dapat dilakukan karena memenuhi persyaratan bahwa sampel diambil secara random dan data berskala interval. Dalam pengujian, kriteria untuk menolak atau tidak menolak $H_{0}$ berdasarkan $P$-value adalah sebagai berikut:

- Jika $P$-Value $<\alpha$, maka $H_{0}$ diterima

- Jika $P$-Value $>\alpha$, maka $H_{0}$ ditolak.

Catatan: Dalam program SPSS 17 digunakan istilah significance (yang disingkat Sig.) untuk P-Value; dengan kata lain $P$-Value $=$ Sig.

Hasil uji normalitas dengan memanfaatkan bantuan software SPSS 17 dapat dilihat pada Tabel 2 berikut:

Tests of Normality

\begin{tabular}{|l|r|r|r|}
\hline \multirow{2}{*}{} & \multicolumn{3}{|c|}{ Kolmogorov-Smirnov } \\
\cline { 2 - 4 } & Statistic & \multicolumn{1}{c|}{$\mathrm{df}$} & \multicolumn{1}{c|}{ Sig. } \\
\hline Kalkulus A & .105 & 65 & .072 \\
Kalkulus B & .103 & 65 & .083 \\
Kalkulus Lanjut & .103 & 65 & .085 \\
PD & .102 & 65 & .092 \\
\hline
\end{tabular}

a. Lilliefors Significance Correction

Tabel 2 di atas, memperlihatkan bahwa harga P-value untuk masingmasing nilai kalkulus A, kalkulus B, kalkulus lanjutan dan Persamaan diferensial sebesar 0.072, 0.083, 0.085, dan 0.092 lebih besar dari pada taraf signifikannya, yaitu $\alpha=0,05$, maka dapat disimpulkan bahwa $H_{0}$ ditolak dan $H_{1}$ diterima. Dengan kata lain, data hasil belajar mahasiswa pada mata kuliah 
Kalkulus A, Kalkulus B, Kalkulus Lanjut dan Persamaan diferensial berdistribusi normal.

b. Uji Multikolinieritas

Uji ini bertujuan untuk menguji apakah dalam model regresi ditemukan adanya korelasi antara variabel independent. Model yang baik seharusnya tidak terjadi korelasi yang tinggi diantara variabel bebas. Tolerance mengukur variabilitas variabel bebas yang terpilih yang tidak dapat dijelaskan oleh variabel bebas lainnya. Jadi, nilai tolerance rendah sama dengan nilai VIF tinggi (karena VIF $=1$ / tolerance) dan menunjukkan adanya kolinearitas yang tinggi. Berdasarkan aturan variance inflation factor (VIF) dan tolerance, maka apabila VIF melebihi angka 10 atau tolerance kurang dari 0,10 maka dinyatakan terjadi gejala multikolinearitas. Sebaliknya apabila nilai VIF kurang dari 10 atau tolerance lebih dari 0,10 maka dinyatakan tidak terjadi gejala multikolinearitas.

Hasil uji Multikolinieritas dengan memanfaatkan bantuan software SPSS 17 dapat dilihat pada Tabel 3 berikut:

\begin{tabular}{|l|r|r|r|r|}
\hline \multirow{2}{*}{ Model } & \multicolumn{2}{|c|}{$95.0 \%$ Confidence Interval for B } & \multicolumn{2}{c|}{$\begin{array}{c}\text { Collinearity } \\
\text { Statistics }\end{array}$} \\
\cline { 2 - 6 } & Lower Bound & Upper Bound & Tolerance & VIF \\
\hline $1 \quad$ (Constant) & -20.657 & 32.527 & & \\
Kalkulus A & -.295 & .418 & .670 & 1.494 \\
Kalkulus B & .324 & 1.124 & .613 & 1.631 \\
Kalkulus Lanjut & -.314 & .403 & .708 & 1.413 \\
\hline
\end{tabular}

Tabel 3 di atas, memperlihatkan bahwa harga VIF tidak berada di atas 10 dan tolerance tidak berada di bawah 0,10, maka dapat disimpulkan bahwa tidak terdapat gejala multikolinieritas.

c. Uji Autokorelasi

Autokorelasi dapat diartikan sebagai korelasi yang terjadi diantara anggota-anggota dari serangkaian observasi yang berderetan waktu. Uji autokorelasi digunakan untuk mengetahui ada tidaknya penyimpangan asumsi klasik autokorelasi, yaitu korelasi yang terjadi antara residual pada satu 
pengamatan dengan pemgamatan lain pada model regersi. Pengujian ini menggunakan Durbin Watson (DW-test). Ketentuan uji DW dapat dilihat Tabel 4 berikut :

Tabel 4 Kriteria Nilai Uji Durbin Watson

\begin{tabular}{|c|c|c|}
\hline No & Nilai DW & Kesimpulan \\
\hline 1 & $1,65<\mathrm{DW}<2,35$ & tidak ada autokorelasi \\
\hline 2 & $1,21<\mathrm{DW}<1,65$ & \multirow{2}{*}{ tidak dapat disimpulkan } \\
\cline { 1 - 2 } 3 & $2,35<\mathrm{DW}<2,79$ & \\
\cline { 1 - 2 } 4 & $\mathrm{DW}<1,21$ & \multirow{2}{*}{ terjadi autokorelasi } \\
\cline { 1 - 2 } 5 & $\mathrm{DW}>2,79$ & \\
\hline
\end{tabular}

Sumber : Wahid Sulaiman (2004)

Hasil uji Multikolinieritas dengan memanfaatkan bantuan software SPSS 17 dapat dilihat pada Tabel 5 berikut:

\begin{tabular}{|r|r|r|r|r|r|}
\hline $\begin{array}{c}\text { Mode } \\
\text { I }\end{array}$ & R & R Square & $\begin{array}{c}\text { Adjusted R } \\
\text { Square }\end{array}$ & $\begin{array}{l}\text { Std. Error of } \\
\text { the Estimate }\end{array}$ & $\begin{array}{c}\text { Durbin- } \\
\text { Watson }\end{array}$ \\
\hline 1 & $.541^{\mathrm{a}}$ & .293 & .258 & 10.69637 & 1.904 \\
\hline
\end{tabular}

Tabel 5 di atas, memperlihatkan bahwa harga Durbin-Watson (DW) berada diantara 1,65 $\leq \mathrm{DW} \leq 2$, maka dapat disimpulkan bahwa tidak terjadi gangguan autokorelasi.

d. Uji Heteroskedasitisitas

Uji heteroskedastisitas bertujuan untuk menguji apakah dalam model regresi terjadi ketidaksamaan varian dari residual satu pengamatan ke pengamatan yang lain. Jika varian dari residual satu pengamatan kepengamatan yang lain tetap, maka disebut homoskedastisitas dan jika berbeda akan disebut heteroskedastisitas. Model regresi yang baik adalah model yang tidak terjadi heteroskedastisitas (Ghozali, 2009). Metode yang dapat dipakai untuk mendeteksi gejala heterokedasitas dalam penelitian ini adalah metode grafik.

Untuk mengetahui ada tidaknya heteroskedastisitas antar variabel independen dapat dilihat dari grafik plot antara nilai prediksi variabel terikat 
(ZPRED) dengan residualnya (SRESID). Ada tidaknya gejala heteroskedastisitas dapat diketahui dengan dua hal, antara lain :

a) Jika pencaran data yang berupa titik-titik membentuk pola tertentu dan beraturan, maka terjadi masalah heteroskedastisitas.

b) Jika pencaran data yang berupa titik-titik tidak membentuk pola tertentu dan menybar diatas dan dibawah sumbu $\mathrm{Y}$, maka tidak terjadi masalah heteroskedastisitas.

Hasil uji heteroksidisitas dengan memanfaatkan bantuan software SPSS 17 dapat dilihat pada Gambar 1 berikut:

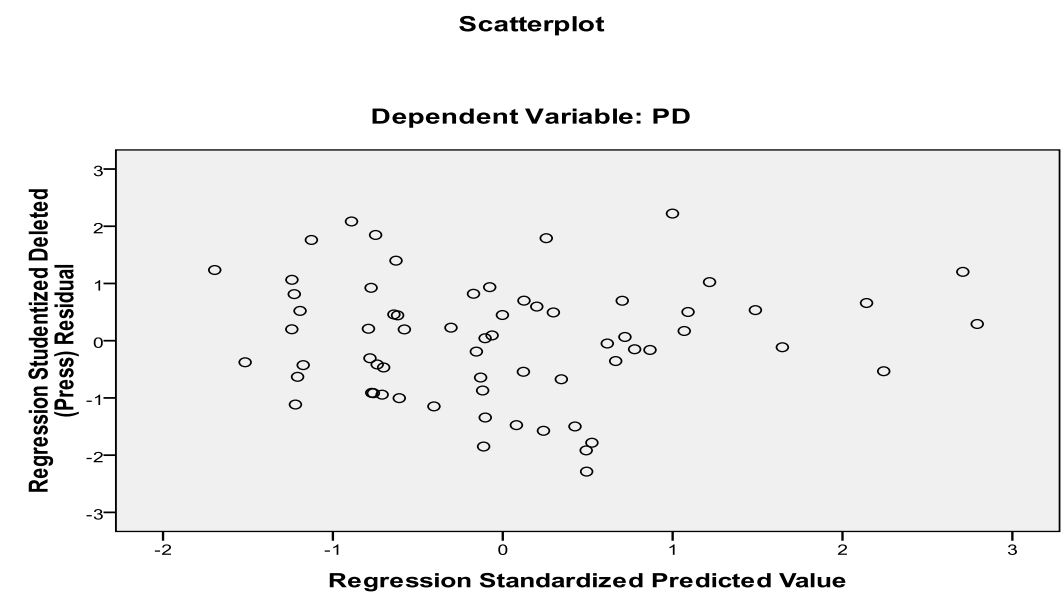

Berdasarkan gambar 1 terlihat bahwa nilai error tidak membentuk pola tertentu dan acak terhadap nol, maka dapat disimpulkan bahwa tidak terjadi heteroskedastisitas.

5. Analisis Jalur

Setelah asumsi klasik terpenuhi, maka data dapat dianalisis dengan menggunakan teknik analisis jalur. Adapun langkah-langkah pengujian analisis jalur diantaranya (Riduwan dan Sunarto, 2007):

a. Merumuskan hipotesis dan persamaan strukturalnya,

b. Menghitung koefisien jalur yang didasarkan pada koefisien regresi

c. Menghitung koefisien jalur secara simultan (keseluruhan)

d. Pengujian secara individual

e. Memaknai analisis jalur 


\section{Penyajian Data dan Analisis Data}

1. Penyajian Data

Penyajian data yang dimaksud dalam penelitian ini adalah mendeskripsikan data sekunder, yaitu data mengenai nilai mata kuliah kalkulus A (X1), nilai kalkulus B (X2), nilai kalkulus lanjut $(X 3)$, dan nilai persamaan diferensial $(Y)$.

\section{a. Deskripsi Data Nilai Kalkulus A}

Deskripsi mengenai data nilai kalkulus A mahasiswa pendidikan matematika angkatan 2011/2012 fakultas tarbiyah dan keguruan IAIN Antasari Banjarmasin yang berjumlah 65 orang ditampilkan pada Gambar 2 berikut.

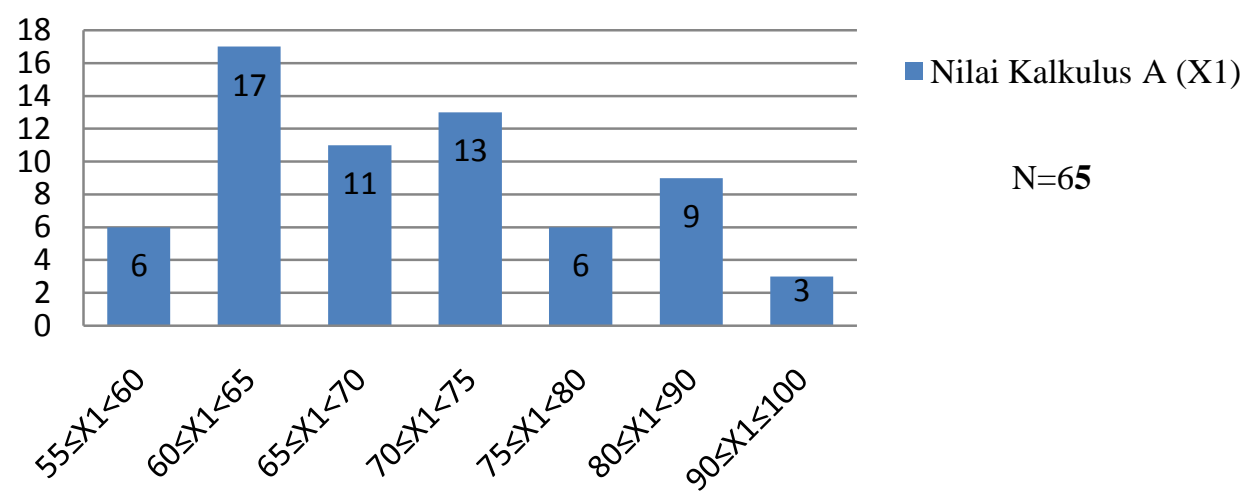

Gambar 2 Frekuensi Data Nilai Kalkulus A

Dari Gambar 2 terlihat bahwa frekuensi nilai minimal, nilai maksimal dan nilai yang mempunyai frekuensi terbesar yang diperoleh mahasiwa terhadap nilai kalkulus A berturut-turut adalah berada pada selang $55 \leq X 1<60$ sebanyak 6 orang atau 9,23\%, $90 \leq X 1 \leq 100$ sebanyak 3 orang atau 4,62\% dan $60 \leq X 1<65$ sebanyak 17 orang atau 26,16\%. Hal ini mengindikasikan sebagian besar nilai kalkulus $A$ mahasiswa berkualifikasi $C$ dengan bobot 2,0.

b. Deskripsi Data Nilai Kalkulus B

Deskripsi mengenai data nilai kalkulus B ditampilkan pada Gambar 3 berikut. 


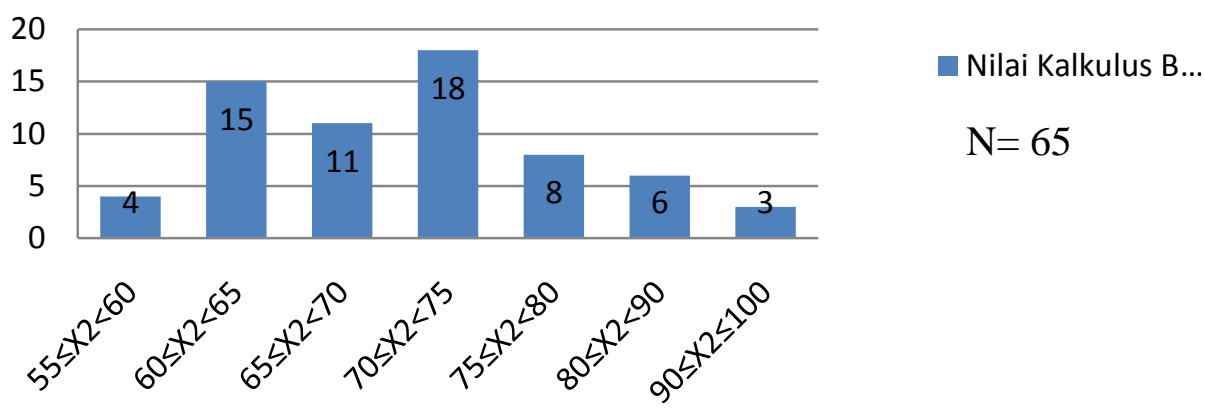

Gambar 3 Frekuensi Data Nilai Kalkulus B

Dari Gambar 3 terlihat bahwa frekuensi nilai minimal, nilai maksimal dan nilai yang mempunyai frekuensi terbesar yang diperoleh mahasiwa terhadap nilai kalkulus B berturut-turut adalah berada pada selang $55 \leq X 2<60$ sebanyak 4 orang atau $6,15 \%, 90 \leq X 2 \leq 100$ sebanyak 3 orang atau $4,62 \%$ dan $70 \leq X 2<75$ sebanyak 18 orang atau $27,69 \%$. Hal ini juga mengindikasikan sebagian besar nilai kalkulus B mahasiswa berkualifikasi B dengan bobot 3,0.

c. Deskripsi Data Nilai Kalkulus Lanjutan

Deskripsi data nilai kalkulus Lanjutan ditampilkan pada Gambar 4 berikut.

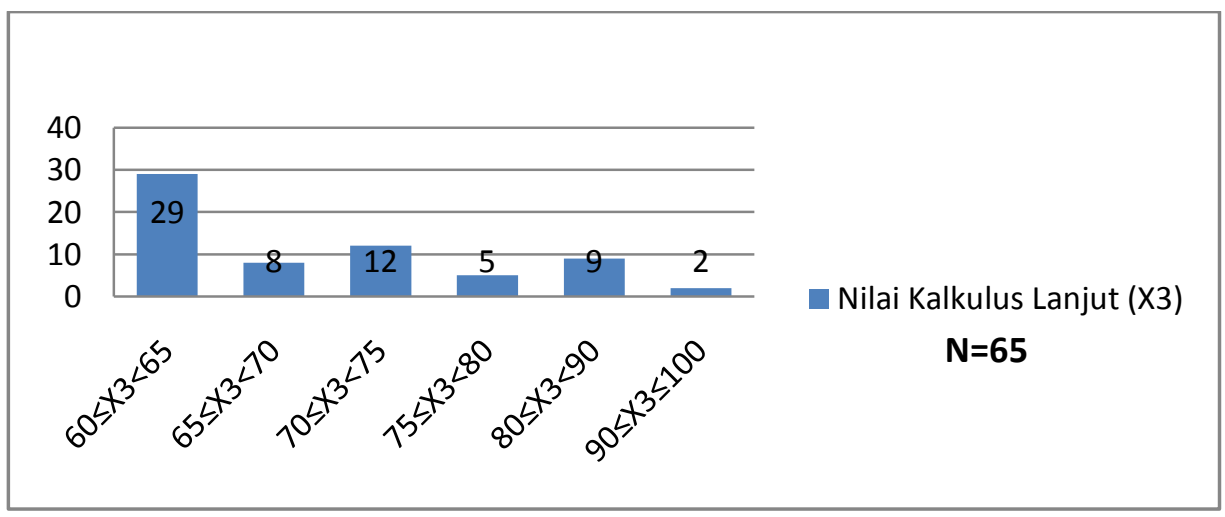

Gambar 4 Frekuensi Data Nilai Kalkulus Lanjutan

Dari Gambar 4 terlihat bahwa frekuensi nilai minimal, nilai maksimal dan nilai yang mempunyai frekuensi terbesar yang diperoleh mahasiwa terhadap nilai kalkulus Lanjutan berturut-turut adalah berada pada selang 60 $\leq X 1<65$ sebanyak 29 orang atau 44,62\%, $90 \leq X 1 \leq 100$ sebanyak 2 orang 
atau 3,08\% dan $60 \leq X 1<65$ sebanyak 29 orang atau 44,62\%. Hal ini juga memberikan arti bahwa nilai ferekuensi terbanyak mahasiswa juga terletak pada selang nilai minimal. Dengan demikian dapat disimpulkan sebagian besar nilai kalkulus multivariabel mahasiswa berkualifikasi $C$ dengan bobot 2,0 .

d. Deskripsi Data Nilai Persamaan Diferensial

Deskripsi Data Nilai Persamaan Diferensial ditampilkan pada Gambar 5 berikut.

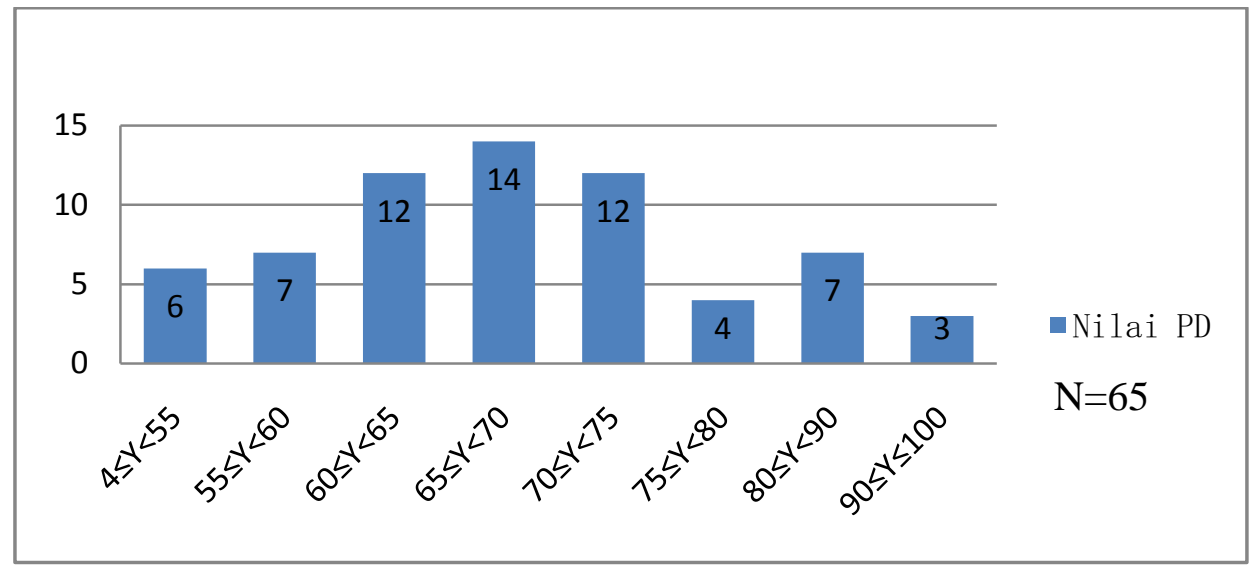

Gambar 5 Frekuensi Data Nilai Persamaan Diferensial

Dari Gambar 5 terlihat bahwa frekuensi nilai minimal, nilai maksimal dan nilai yang mempunyai frekuensi terbesar yang diperoleh mahasiwa terhadap nilai kalkulus Lanjutan berturut-turut adalah berada pada selang $4 \leq$ $X 1<55$ sebanyak 6 orang atau 9,23\%, $90 \leq X 1 \leq 100$ sebanyak 3 orang atau 4,62\% dan $65 \leq X 1<70$ sebanyak 14 orang atau $21,54 \%$. Hal ini juga memberikan indikasi bahwa nilai mahasiswa terhadap mata kuliah persamaaan diferensial sebagian besar berkualifikasi $C_{+}$dengan bobot 2,5.

2. Analisis Data

a. Hasil Pendugaan dan Pengujian Koefisen-Koefisien Jalur Pada Model Analisis Jalur

Ringkasan hasil dalam pendugaan koefisien-koefisien jalur pada model analisis jalur yang dihasilkan oleh program lisrel disajikan pada Tabel 6 berikut. 
Tabel 6. Hasil Pendugaan dan Pengujian Koefisien- koefisien Jalur

\begin{tabular}{|l|c|c|}
\hline \multicolumn{1}{|c|}{ Komposisi Pengaruh } & $\begin{array}{c}\text { Koefisien } \\
\text { Jalur }\end{array}$ & $\begin{array}{c}\text { Nilai } \\
\mathrm{T}\end{array}$ \\
\hline Kalkulus $\mathrm{A} \rightarrow$ Kalkulus B & 0.56 & $5.42 *$ \\
\hline Kalkulus A $\rightarrow$ Kalkulus Lanjutan & 0.38 & $3.37 *$ \\
\hline Kalkulus A $\rightarrow$ Persamaan Diferensial & 0.25 & $2.10 *$ \\
\hline Kalkulus B $\rightarrow$ Kalkulus Lanjutan & 0.40 & $3.54 *$ \\
\hline Kalkulus B $\rightarrow$ Persamaan Diferensial & 0.33 & $2.74 *$ \\
\hline Kalkulus Lanjutan $\rightarrow$ Persamaan Diferensial & 0.24 & 1.90 \\
\hline
\end{tabular}

*Nilai T nyata $\mathrm{p}=0.0$ untuk $\mathrm{N}=65$ didapat nilai $\mathrm{T}$ tabel $=2,0$.

Berdasarkan Tabel 6 di atas terlihat bahwa hasil pendugaan koefisienkoefisien jalur pada model analisis jalur menunjukkan bahwa seluruh variabel eksogen berpengaruh nyata terhadap variabel endogen kecuali pada matakuliah kalkulus Lanjutan tidak berpengaruh nyata terhadap mata kuliah persamaan diferensial karena nilai $\mathrm{T}$ hitung $<\mathrm{T}$ tabel.

b. Interpretasi Hasil pendugaan koefisien-koefisien Jalur

Sebagaimana yang telah dijelaskan sebelumnya bahwa variabel eksogen berpengaruh nyata terhadap variabel endogen kecuali pada mata kuliah kalkulus Lanjutan tidak berpengaruh nyata terhadap mata kuliah persamaan diferensial. Untuk lebih jelas lagi dalam melihat besar masing-masing pengaruh tersebut dapat dilihat pada Gambar 6 yang dihasilkan oleh output lisrel berkut.

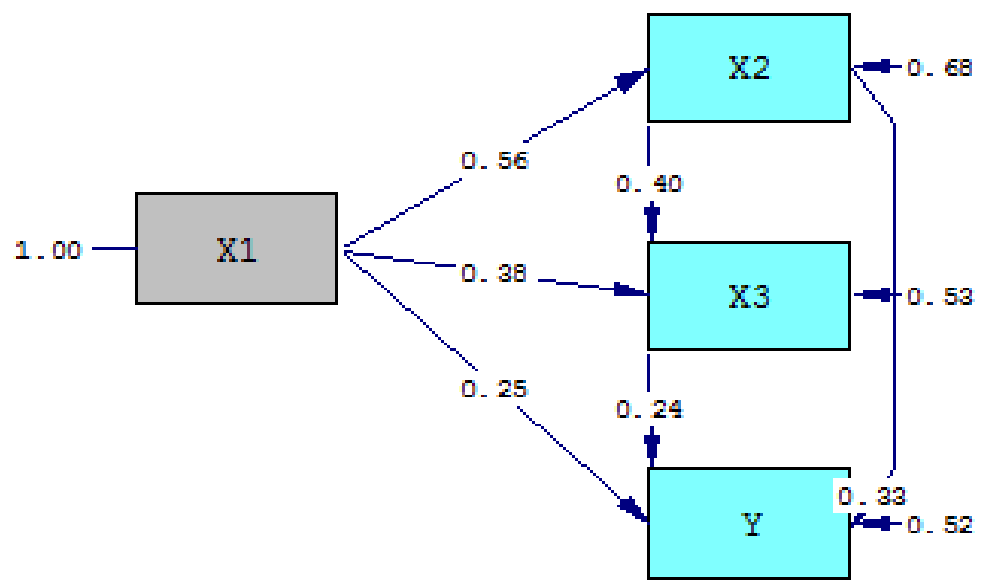

Gambar 6 Hasil Pendugaan Koefisien - Koefisien Jalur 
Berdasarkan Gambar 6 dan nilai T yang disajikan pada Tabel 2 maka dapat dihitung pengaruh langsung, tidak langsung dan total pengaruh dari masing masing variabel eksogen terhadap variabel endogen yang dipaparkan dalam uraian berikut ini.

a) Pengaruh Kalkulus A Terhadap Kalkulus B

Berdasarkan nilai-nilai yang ada pada Gambar 5 diketahui bahwa besar koefisien Jalur dari kalkulus A terhadap kalkulus B sebesar 0.56 dengan arah positif, artinya semakin meningkat nilai kalkulus A mahasiswa maka akan membuat nilai kalkulus B mahasiswa meningkat. Besar pengaruh kalkulus A terhadap kalkulus B secara langsung sebesar $(0.56)^{2}=0.3136$ atau $31.36 \%$. Jadi berdasarkan hasil penelitian diketahui bahwa $31.36 \%$ peningkatan yang terjadi pada nilai kalkulus B secara langsung disebabkan oleh adanya peningkatan pada nilai Kalkulus $A$.

b) Pengaruh Kalkulus A Terhadap Kalkulus Lanjutan

Berdasarkan nilai-nilai yang ada pada Gambar 5 diketahui bahwa besar koefisien Jalur dari kalkulus A terhadap kalkulus lanjutan sebesar 0.38 dengan arah positif, artinya semakin meningkat nilai kalkulus A mahasiswa maka akan membuat nilai kalkulus lanjutan mahasiswa meningkat. Besar pengaruh kalkulus A terhadap kalkulus lanjutan secara langsung sebesar $(0.38)^{2}=$ 0.1444 atau $14.44 \%$. Jadi berdasarkan hasil penelitian diketahui bahwa $14.44 \%$ peningkatan yang terjadi pada nilai kalkulus Lanjutan secara langsung disebabkan oleh adanya peningkatan pada nilai kalkulus A. Sementara secara tidak langsung pengaruh kalkulus A terhadap kalkulus lanjutan melalui kalkulus B sebesar $(0.56 \times 0.40)=0.224$ atau $22.4 \%$. Jadi secara total pengaruh kalkulus A terhadap kalkulus lanjutan sebesar $36.84 \%$.

C) Pengaruh Kalkulus A Terhadap Persamaan Diferensial

Berdasarkan nilai-nilai yang ada pada Gambar 5 diketahui bahwa besar koefisien Jalur dari kalkulus A terhadap persamaan diferensial sebesar 0.25 dengan arah positif, artinya semakin meningkat nilai kalkulus A mahasiswa maka akan membuat nilai persamaan diferensial mahasiswa meningkat. Besar pengaruh kalkulus A terhadap persamaan diferensial secara langsung sebesar 
$(0.25)^{2}=0.0625$ atau $6.25 \%$. Jadi berdasarkan hasil penelitian diketahui bahwa $6.25 \%$ peningkatan yang terjadi pada nilai persamaan diferensial secara langsung disebabkan oleh adanya peningkatan pada nilai kalkulus $A$. Sementara secara tidak langsung pengaruh kalkulus A terhadap persamaan diferensial melalui kalkulus B dan kalkulus Lanjutan sebesar $(0.56 \times 0.40 \times$ $0.24)+(0.56 \times 0.33)+(0.38 \times 0.24)=0.3298$ atau $32.98 \%$. Jadi secara total pengaruh kalkulus A terhadap persamaan diferensial sebesar 39.23\%.

d) Pengaruh Kalkulus B Terhadap Kalkulus Lanjutan

Berdasarkan nilai-nilai yang ada pada Gambar 5 diketahui bahwa besar koefisien Jalur dari kalkulus B terhadap kalkulus lanjutan sebesar 0.40 dengan arah positif, artinya semakin meningkat nilai kalkulus A mahasiswa maka akan membuat nilai kalkulus lanjutan mahasiswa meningkat. Besar pengaruh kalkulus A terhadap kalkulus lanjutan secara langsung sebesar $(0.40)^{2}=0.16$ atau $16 \%$. Jadi berdasarkan hasil penelitian diketahui bahwa 16\% peningkatan yang terjadi pada nilai kalkulus Lanjutan secara langsung disebabkan oleh adanya peningkatan pada nilai kalkulus $B$.

e) Pengaruh Kalkulus B Terhadap Persamaan Diferensial

Berdasarkan nilai-nilai yang ada pada Gambar 5 diketahui bahwa besar koefisien jalur dari kalkulus B terhadap persamaan diferensial sebesar 0.33 dengan arah positif, artinya semakin meningkat nilai kalkulus B mahasiswa maka akan membuat nilai persamaan diferensial mahasiswa meningkat. Besar pengaruh kalkulus B terhadap persamaan diferensial secara langsung sebesar $(0.33)^{2}=0.1089$ atau $10.89 \%$. Jadi berdasarkan hasil penelitian diketahui bahwa $10.89 \%$ peningkatan yang terjadi pada nilai persamaan diferensial secara langsung disebabkan oleh adanya peningkatan pada nilai kalkulus $B$. Sementara secara tidak langsung pengaruh kalkulus B terhadap persamaan diferensial melalui kalkulus Lanjutan sebesar $(0.40 \times 0.24)=0.096$ atau 9.6\%. Jadi secara total pengaruh kalkulus B terhadap persamaan diferensial sebesar $20.49 \%$.

f) Pengaruh Kalkulus Lanjutan Terhadap Persamaan Diferensial 
Berdasarkan nilai-nilai yang ada pada Gambar 5 diketahui bahwa besar koefisien jalur dari kalkulus Lanjutan terhadap persamaan diferensial sebesar 0.24 dengan arah positif. Namun dari hasil perhitungan sebelumnya telah diketahui bahwa kalkulus Lanjutan tidak berpengaruh nyata (signifikan) terhadap persamaan diferensial. Hal ini berarti berapapun peningkatan yang terjadi pada nilai kalkulus multivariaber tidak memberikan kontribusi yang berarti bagi nilai persamaan diferensial.

Formulasi model struktural mata kuliah persamaan difrensial adalah sebagai berikut:

Persamaan diferensial $=0.25 *$ Kalkulus $A+0.33 *$ Kalkulus $\mathrm{B}+0.52$, dengan $R^{2}=0.60$. Hal ini memberikan arti bahwa keragaman persamaan diferensial dapat dijelaskan oleh keragaman kalkulus A dan kalkulus B sebesar 60\%, sedangkan sisanya yaitu, 40\% dimungkinkan dijelaskan oleh mata kuliah lain yang bukan prasyarat. Dari hasil perhitungan juga terlihat bahwa kalkulus $B$ mempunyai pengaruh yang paling besar terhadap persamaan diferensial. Hal ini dapat diterima karena berdasarkan hasil deskripsi data pada bagian terdahuhu diketahui sebagian besar nilai kalkulus B mahasiswa berkualifikasi B dengan bobot 3,0 artinya mahiswa cukup menguasai terhadap materi matakuliah kalkulus B sehingga ketika materi kalkulus B diperlukan pada mata kuliah persamaan diferensial mahasiswa tidak mengalami kesulitan. Selanjutnya mungkin menjadi pertanyaan bagi kita mengapa mata kuliah kalkulus Lanjutan tidak berpengaruh nyata terhadap mata kuliah persamaan diferensial ? padahal telah kita ketahui bahwa mata kuliah kalkulus Lanjutan juga merupakan mata kuliah prasyarat bagi persamaan diferensial. Hal ini mungkin disebabkan: i) karena rendahnya nilai kalkulus Lanjutan yang diperoleh masiswa, seperti yang juga kita ketahui dari hasil deskipsi data sebelumnya bahwa nilai kalkulus Lanjutan mahasiswa sebagian besar berkualifikasi $C$ dengan bobot 2,0. Hal ini juga memberikan arti bahwa mahasiswa tidak terlalu menguasai materi kalkulus Lanjutan sehingga ketika materi kalkulus Lanjutan diperlukan pada mata kuliah persamaan diferensial mahasiswa akan mengalami kesulitan, ii) karena dimungkinkan materi kalkulus 
Lanjutan tidak terlalu relevan menjadi prasyarat untuk mata kuliah persamaan diferensial. Dari hasil ini mengisyaratkan bahwa mahasiswa bisa saja memprogram mata kuliah persamaan diferensial meskipun tidak lulus kalkulus Lanjutan (kalau sebab kedua berlaku).

\section{Kesimpulan}

Berdasarkan penelitian yang telah dilakukan dapat diambil kesimpulan bahwa: Kalkulus A berpengaruh nyata terhadap kalkulus B, Kalkulus A berpengaruh nyata terhadap kalkulus Lanjutan dan persamaan diferensial, Kalkulus B berpengaruh nyata terhadap kalkulus Lanjutan dan persamaan diferensial, Kalkulus Lanjutan tidak berpengruh nyata terhadap persamaan diferensial.

\section{DAFTAR PUSTAKA}

Ghozali, Imam. 2009. Ekonometrika Teori, Konsep dan Aplikasi dengan SPSS 17. Badan Penerbit Universitas Diponegoro: Semarang

Hengki Latan. 2012. Structural Equation Modelling; Konsep dan Aplikasi Menggunakan Program LISREL 8.8. Alfabeta: Bandung

Jonathan Sarwono. 2010. PASW Statistics 18. CV. Andi Offset: Yogyakarta

Riduwan dan Sunarto. 2007. Pengantar Statistika Untuk Peneltian Pendidikan, Sosial, Ekonomi, Komunikasi, dan Bisnis. Alfabeta: Bandung

Saifuddin Azwar. 2005. Metode Penelitian. Pustaka Belajar: Yogyakarta

Stanislaus S.Uyanto. 2006. Pedoman Analisis Data dengan SPSS. Graha Ilmu: Jakarta

Suharsimi Arikunto. 2010. Prosedur Penelitian; Suatu Pendekatan Praktik. Rineka Cipta: Jakarta 